\title{
Effect of Different Levels of Gypsum on Pattern of Moisture Use and Aggregation in Vertisols under Soybean-Chickpea Sequence
}

\author{
Kishor R. Shedge1, Priyanka N. Hiradeve ${ }^{2}$ and Prashant B. Kardile ${ }^{3 *}$ \\ ${ }^{1}$ National Centre of Organic Farming, Imphal, Manipur, India \\ ${ }^{2}$ Department of Agriculture Botany, CSMSS, COA, Kanchanwadi, Aurangabad (M.S.), India \\ ${ }^{3}$ Plant Physiology, Department of Agriculture Botany, VNMKV, Parbhani (M.S.), India \\ *Corresponding author
}

\begin{tabular}{|c|c|}
\hline & A B S T R A C T \\
\hline & \multirow{6}{*}{$\begin{array}{l}\text { A field investigation relating to "Effect of levels of gypsum on pattern of moisture use and } \\
\text { aggregation in Vertisols under soybean-chickpea - sequence" was conducted at Agronomy } \\
\text { farm, College of Agriculture, Nagpur. The field experiment was laid out in randomized } \\
\text { block design (RBD) with a seven treatments replicated thrice. Treatments consisted of } 1 \text {, } \\
1.5,2,2.5,3,5 \mathrm{t} \text { gypsum per hectare and a control. The samples were taken from }(0-30 \\
\mathrm{cm}) \text { and }(30-60 \mathrm{~cm}) \text { depth for conducting study. The surface soil of experimental site was } \\
\text { slightly alkaline in reaction clayey in texture, medium in organic carbon }\left(6.21 \mathrm{~kg}^{-1}\right) \text {, low in } \\
\text { available nitrogen }(206.98 \mathrm{~kg}) \text {, medium in phosphorus }\left(19.23 \mathrm{~kg} \mathrm{~h}^{-1}\right) \text {, high in potassium } \\
\left(503.00 \mathrm{~kg} \mathrm{ha}^{-1}\right) \text { poor in hydraulic conductivity }\left(1.06 \mathrm{~cm} \mathrm{ha}^{-1}\right) \text {. The CEC of surface and } \\
\text { subsurface soil was } 52.16 \text { and } 53.70\left[\mathrm{cmol}\left(\mathrm{p}^{+}\right) \mathrm{kg}^{-1}\right] \text { and Ca/Mg ratio of was } 1.30 \text { and } 1.21 \\
\text { respectively. Application of gypsum does not markedly affect the cumulative moisture use } \\
\text { during and at different percent growing season of soybean and chickpea. However MUE of } \\
\text { soybean significantly increased with increasing level of gypsum. Higher MUE was found } \\
\text { with T } \mathrm{T}_{6}\left(3 \mathrm{t} \text { gypsum ha }{ }^{-1}\right) \text { but } \mathrm{T}_{3}\left(1.5 \mathrm{t} \text { gypsum ha }{ }^{-1}\right) \text { is enough to increase MUE of soybean } \\
\text { significantly over no gypsum. Increasing level of gypsum also increase the MUE of } \\
\text { chickpea. }\end{array}$} \\
\hline Keywords & \\
\hline $\begin{array}{l}\text { Gypsum, Vertisols, } \\
\text { Moisture, Soybean, } \\
\text { Chickpea }\end{array}$ & \\
\hline Article Info & \\
\hline $\begin{array}{l}\text { Accepted: } \\
\text { 12 November } 2018 \\
\text { Available Online: } \\
10 \text { December } 2018\end{array}$ & \\
\hline & \\
\hline
\end{tabular}

\section{Introduction}

Vertisols are dark, montmorillonite rich clays, characteristics shrinking and swelling properties and have high clay content $(>30 \%$ up to at least $50 \mathrm{~cm}$ from surface) and produce typical cracks (at least $1 \mathrm{~cm}$ wide reaching a depth of $50 \mathrm{~cm}$ or more). Vertisols and associated vertic soil in peninsular India occurs mostly extending from $8^{\circ} 45^{\prime}$ to $26^{\circ} 0$ ' $\mathrm{N}$ latitude and $66^{\circ} 0$ ' to $83^{\circ} 45^{\prime}$ E longitude covering an area of 73 million ha. The area occupied by Vertisols constitutes nearly $22.2 \%$ of total geographical area of India out of which Maharashtra account for 29.9 million hectares (Murthy, 1982).

The unique properties special to vertisols are high clay content, volume changes with moisture, cracks that split and merge periodically and evidence of soil movement in the form of slicken slides and of wedge shaped 
structural aggregates that are tilted with an angle from the horizon. The shrink-swell phenomenon which is responsible for the genesis and behavior of vertisols is a complex, dynamic and yet incompletely understood set of processes (Gokhan and Aksoy, 2007).

The poor structural stability of Vertisols particularly during the monsoon season render the agricultural activity difficult, the low saturated hydraulic conductivity causes water logging. As a result vast land remain vacant particularly during monsoon season (Sen, 2003).

Increases in ESP and EMP with depth have adversely affected the hydraulic and other properties important for crop growth. Saturation of these soils, not only with $\mathrm{Na}^{+}$ ions but also with $\mathrm{Mg}^{2+}$ ions leads to greater dispersion of clay, which is the opposite effect from that saturation with $\mathrm{Ca}^{2+}$ ions, which leads to the blocking of small pores in the soil. In other words, $\mathrm{Mg}^{2+}$ ions are less efficient than $\mathrm{Ca}^{2+}$ ions in flocculating soil colloids. However due to high evaporative demand for soil water in the semi-arid climatic condition, maintenance of a proper $\mathrm{Ca} / \mathrm{Mg}$ ratio in the soil solution becomes difficult because $\mathrm{Ca}^{2+}$ ion get precipitate as $\mathrm{CaCO}_{3}$ result in depletion of $\mathrm{Ca}^{2+}$ ions from the soil solution (Balpande et al., 1996). The Vertisols have enough $\mathrm{CaCO}_{3}$ but the soluble calcium concentration in the saturation extract of the many Vertisols were is 0.6 to $3.6 \mathrm{mmol} \mathrm{L}^{-1}$ and this amount is not enough to inhibit the swelling of smectite by contracting the diffuse double layer. This indicates the inertness of calcite to inhibit the swelling of smectite (Balpande et al., 1997).

Under rainfed condition yield of crop depends primarily on the amount of rain stored in soil profile and extend to which this water is released during crop growth. More over both retention and release of soil water are governed by the nature and content of clay minerals, and also by the nature of exchangeable cations.

The exchangeable polyvalent cations (e.g. Ca) near clay surfaces reduce the thickness of the diffuse double layer. The reduction in repulsive forces acting between clay particles (Emerson 1983) helps for the flocculation of clays and increased resistance to dispersion (the Schultze- Hardy Rule). Calcium rather than $\mathrm{Mg}$ or $\mathrm{K}$ on the exchange complex was associated with stable aggregates in Australian subsoils (Emerson and Bakker 1973). Pojasok and Kay (1990) found aggregate stability to increase with $\mathrm{Ca}$ concentrations in soil solution.

In the view of above consideration, field experiment entitled "Effect of gypsum on moisture availability in Vertisols under soybean gram sequence" was conducted with following objectives, To study the effect of gypsum on moisture use pattern during the cropping period under soybean and chickpea sequence.

\section{Materials and Methods}

The field investigation in relation to "Effect of levels of gypsum on pattern of moisture use and aggregation in Vertisols under soybeanchickpea sequence", was conducted during Kharif and rabi season at Agronomy Farm, College of Agriculture, Nagpur. The details of material used and methods adopted during the period of investigation are given in this chapter under appropriate heads.

\section{Experimental site}

The field experiment entitled "Effect of levels of gypsum on pattern of moisture use and aggregation in Vertisols under soybeanchickpea sequence", was carried out at Extra Assistant Director (EAD) farm, College of 
Agriculture Nagpur. The field selected for conducting experiment was fairly uniform and leveled (Table 1).

\section{Soil of experimental area}

The soil under the experimental study was fine montmorillonite of Typic Haplustert. In order to study the physical and chemical properties soil samples were taken from 0-30 and 30-60 $\mathrm{cm}$ depth with the help of screw auger from randomly selected spots over the experimental field before sowing. The soil of the experimental field was clay in texture. The result of the chemical analysis data indicate that soil was low in available nitrogen, medium in available phosphorus, very high in available potassium, medium in organic carbon, low in available sulphur soil $\mathrm{pH}$ was 8.10 and electrical conductivity recorded 0.20 $\mathrm{dS} \mathrm{m}^{-1}$

\section{Climate and weather conditions}

Nagpur is situated at $21^{\circ} 10^{\prime}$ North latitude and $19^{\circ} 19^{\prime}$ 'East latitude at elevation of 321.26 meter above sea level and lies under subtropical zone. Nagpur is characterized by hot and dry summer and fairly cold winter. This area shows wide diurnal fluctuation in temperature. The maximum and minimum temperature ranged from 43.3 to $8.5^{\circ} \mathrm{C}$ respectively. Whereas relative humidity varied from $13 \%$ to $90 \%$. During the crop growth period mean annual precipitation was about $928.8 \mathrm{~mm}$ and major amount of it is received from June to December within 46 rainy days.

\section{Experimental details}

\section{Design of experiment and treatments}

The experiment was laid out in randomized block design (RBD) with seven treatments each replicated thrice, the detail of treatment are presented below.

\section{Treatment details}

$\mathrm{T}_{1}$ : Control (no Gypsum)

$\mathrm{T}_{2}: 1.0 \mathrm{t} \mathrm{ha}^{-1}$ gypsum

$\mathrm{T}_{3}: 1.5 \mathrm{t} \mathrm{ha}^{-1}$ gypsum

$\mathrm{T}_{4}: 2.0 \mathrm{t} \mathrm{ha}^{-1}$ gypsum

$\mathrm{T}_{5}: 2.5 \mathrm{t} \mathrm{ha}^{-1}$ gypsum

$\mathrm{T}_{6}: 3.0 \mathrm{t} \mathrm{ha}^{-1}$ gypsum

$\mathrm{T}_{7}: 5.0 \mathrm{t} \mathrm{ha}^{-1}$ gypsum

\section{Fertilizer application}

The fertilizer application was done as per recommended doses (experimental details) for both the crop. Nitrogen and phosphorus were applied through Urea and SSP respectively, fertilizers doses were applied to different plot at the time of sowing.

\section{Methodology for gypsum application}

Gypsum in powder form was applied to different plots as per treatments before sowing of soybean crop. The proper care was taken for equal mixing of gypsum in surface soil and for that after application of gypsum to soil it was equalized by turning surface soil.

\section{Soil sampling and processing}

Initial treatment wise soil samples from (0-30 $\mathrm{cm})$ and $(30-60 \mathrm{~cm})$ depth after harvest of soybean were collected. The soil samples were dried in shade and gently grind with wooden pestle and mortar and sieved through $2 \mathrm{~mm}$ sieve. These samples were stored in polythene bags and were subsequently analysed for various properties.

\section{Collection of soil sample for soil moisture study}

The treatment wise soil samples were collected with the help of screw auger from $(0-30 \mathrm{~cm})$ and $(30-60 \mathrm{~cm})$ depth between the two rows at an interval of 15 . These samples 
were immediately put in pre weighed aluminum boxes for determination of moisture content by gravimetric method.

\section{Determination of moisture use efficiency (MUE)}

\section{Soil moisture studies}

The initial weights of the soil sample along with aluminum boxes were recorded immediately on electronic balance. Then the aluminum boxes along with soil samples were kept in hot air oven at $105^{\circ} \mathrm{C}$ up to constant weight obtained and final dry weights were recorded. The soil moisture was determined by gravimetric method. The moisture percent was calculated by using following formula.

Gravimetric moisture content $(\%)=$ $\frac{\mathrm{w}_{1}-\mathrm{w}_{2}}{\mathrm{w}_{2}} \times 100$

Where,

Moisture

$(\mathrm{mm})$ during $\mathrm{a}=(\mathrm{mm})$ up to $60+\operatorname{period}(\mathrm{mm})$ period $\mathrm{w}_{1}$ : Initial weight of soil

$\mathrm{w}_{2}$ : Oven dry weight of soil

Soil moisture in profile during different period of crop growth

Soil moisture up to depth $60 \mathrm{~cm}$ was calculated as follows.

1. Soil moisture (mm)

in $0-30 \mathrm{~cm}$ layer depth = \% Gravimetric moisture x bulk density $\times 300$ 100

2. Soil moisture $(\mathrm{mm})$ in $30-60 \mathrm{~cm}$ layer depth = \% Gravimetric moisture $\mathrm{x}$ bulk density $\times 300$ 100

\section{Moisture use by crop during a period}

Moisture use by crop during a period was calculated as follows:
Soil moisture up to $60 \mathrm{~cm}$ depth at the first period is considered as initial soil moisture for second period and likewise.

Total moisture use $(\mathrm{mm})=\sum_{\mathrm{i}=1}^{\mathrm{n}}$ moisture use during different periods.

\section{Percent growing season of the crop}

Moisture use during different periods (percent growing season) at different intervals of soil sampling was expressed in terms of percent growing season of the crop which was calculated on the basis of duration of crop.
Percent growing season $=$

$\underline{\text { Number of days of sampling }} \times 100$ Duration of the crop

\section{Moisture use efficiency (MUE)}

Moisture use efficiency for each treatment was calculated on the basis of economic yield of the crop and total moisture use by that crop in given treatment by Michael and Ojha, (1983).

$\operatorname{MUE}\left(\mathrm{kg} \mathrm{ha}^{-1} \mathrm{~mm}^{-1}\right)=$

$\frac{\text { Crop yield }\left(\mathrm{kg} \mathrm{ha}^{-1}\right)}{\text { Total moisture use }(\mathrm{mm})}$ 


\section{Results and Discussion}

The present investigation entitled "Effect of levels of gypsum on pattern of moisture use and aggregation in Vertisols under soybeanchickpea-sequence" were carried out by conducting a field trial of soybean and chickpea. The results obtained and inferences drawn were discussed under following heads.

2.1 Physical and chemical properties of vertisols of the experimental site

2.2 Moisture content in soil during cropping period.

2.3 Moisture use and its use pattern by crops.

2.4 Assessment of moisture availability period (growing period).

\section{Physical and chemical properties of vertisols of the experimental site}

The soil of the experimental field was clay in texture. The result of the chemical analysis indicated that soil was low in available nitrogen, medium in available phosphorus, very high in available potassium, medium in organic carbon, low in available sulphur soil $\mathrm{pH}$ was 8.10 and electrical conductivity recorded $0.20 \mathrm{dS} \mathrm{m}^{-1}$

\section{Moisture content in soil during cropping period}

Moisture content in soil largely depends on climatic factors i.e. rainfall pattern, rate of PET and storage in soil. Soil moisture content (gravimetric) at $0-30 \mathrm{~cm}$ and $30-60 \mathrm{~cm}$ depth were determined. Moisture percentage in soil was increased from $6^{\text {th }}$ July 2009 to $21^{\text {st }}$ July 2009 due to occurrence of rain during that period. After that less moisture was observed in soil up to $20^{\text {th }}$ August and it suddenly increased on $5^{\text {th }}$ September 2009 due to heavy rain. After that it decreased upto $7^{\text {th }}$ October 2009 . Further at $23^{\text {rd }}$ October moisture content was found to increase due to irrigation for the seedbed preparation of the chickpea crop. During cropping period highest moisture percentage was found at 21 st July in the range of 37.18 to $40.31 \%$ in surface and 35.21 to $39.18 \%$ in sub surface soil. Lowest moisture percentage at surface soil was found at $7^{\text {th }}$ October 2009 in the range of 16.48 to $21.19 \%$ and at subsurface soil was found in the range of 16.49 to 20.18 percent. It was also noticed that decrease in moisture percentage in surface soil is much faster than sub-surface soil, which may be due to utilization of moisture by the crop (Kadiappa et al., 1974) and more evaporation from the surface. The climatic moisture balance and actual moisture storage is detected. The actual moisture storage is less than the climatic moisture balance.

\section{Moisture use and its use pattern by crops}

Total moisture use by soybean crop was determined considering the rainfall and actual soil moisture availability from sowing to harvesting stage.

Cumulative moisture use $(\mathrm{mm})$ at different percent of growing season of soybean and chickpea

The data pertaining to cumulative observed moisture use at different percent of growing season of soybean (JS-335) and chickpea (JAKI -9218) under various treatment are presented in table 2(a) and 2(b). Moisture use value at percent growing season of crop were calculated for each treatment which showed little variation in cumulative moisture use at different percent growing season of crop.

It is seen that, soybean crop used moisture in range of 613.6 to $691.6 \mathrm{~mm}$ and chickpea crop used moisture in range of 169.14 to 224.78 $\mathrm{mm}$ within the various levels of gypsum. 
Moisture use decreases with increasing levels of gypsum. Highest moisture use recorded in control. The lower moisture use was recorded in $\mathrm{T}_{7}$ (5.0 $\mathrm{t}$ gypsum per hectare) followed by $\mathrm{T}_{6}$ (3 $\mathrm{t}$ gypsum per hectare) and $\mathrm{T}_{3}(1.5 \mathrm{t}$ gypsum per hectare)

Total moisture use during growing season of soybean decreased with increased level of gypsum which indicates better utilization and storage soil moisture during the growth period.

For soybean cumulative moisture use under different treatment varied between 32.55 to $35.36 \%$ at 33.3 percent growing season of crop, 36.69 to $42.73 \%$ at 50.53 percent growing season of crop as against 76.79 to $87.40 \%$ at 83.87 percent growing season of crop indicating about 85 percent of total moisture use during 0-85 per cent growing season of crop and less moisture used during later period.

In case of chickpea cumulative moisture use under different treatment varied between 28.07 to $32.80 \%$ of total moisture use at 28.12 per cent growing season of crop. Cumulative moisture use varied between 62.64 to $79.41 \%$ at 64.84 percent growing season, as against 82.76 to 92.19 percent at 76.56 percent growing season indicating about 90 percent of total moisture use during 0-76 percent growing season of crop and less moisture used during later period.

Patil (1987) noted that 64.3 to $65.9 \%$ of total moisture use for different treatment by end of 70 percent of growing season. Kalane et al., (1990) and Dhopte (1994) reported linear increase of moisture use with percent growing season of hybrid Sorghum CSH-9. Differences in consumptive use and water use efficiency in different crops may be due to genetic variability in plant type and yield potential.
In soybean maximum moisture use was recorded in $\mathrm{T}_{1}$ (no gypsum) treatment (691.6 $\mathrm{mm})$, followed by $\mathrm{T}_{2}(648.0), \mathrm{T}_{4}(641.9 \mathrm{~mm})$ $\mathrm{T}_{5}(628.3 \mathrm{~mm}), \mathrm{T}_{3}(626.3 \mathrm{~mm})$ and least moisture use recorded by $\mathrm{T}_{7}\left(5 \mathrm{t}\right.$ gypsum $\left.\mathrm{ha}^{-1}\right)$ treatment (613.6). However not much variation in total moisture use was found in various treatments.

In case of chickpea total moisture used ranged between 169.4 to $224.78 \mathrm{~mm}$, where maximum moisture use was recorded by $\mathrm{T}_{2}(1$ $\mathrm{t}$ gypsum ha ${ }^{-1}$ ) treatment followed by $\mathrm{T}_{6}$ $(199.49 \mathrm{~mm}), \mathrm{T}_{5}(197.79 \mathrm{~mm})$ and least moisture use recorded by $\mathrm{T}_{7}$ (169.14). However not much variation in total moisture use was found under different treatment.

\section{Moisture use by soybean and chickpea during different period of percent growing season of crop}

Calculated moisture use during different period of percent growing season of crop presented in table 2(a) and 2(b). The data in table 2(a) showed that, in soybean cumulative moisture use during different percent of growing season of crop i.e. 0 to $33.3 \%, 33.3$ to $67.74 \%$ and 67.74 to $100.0 \%$ growing season varied over narrow range 208.97 to 242.88 $\mathrm{mm}, 192.35$ to $224.08 \mathrm{~mm}$ and 187.61 to $256.37 \mathrm{~mm}$ respectively under different treatments.

This showed that moisture use during early period i.e. 0 to $67.74 \%$ growing season was more and it further decreased during 67.74 percent growing season of soybean crop under all treatments.

The data in table 2(b) showed that in chickpea cumulative moisture use during different percent of growing season of crop i.e. 0 to $28.12 \%, 28.12$ to $76.56 \%$ and 76.56 to $100.0 \%$ growing season varied over 51.1 to $65.45 \mathrm{~mm}$, 94.91 to $135.87 \mathrm{~mm}$ and 13.2 to $30.4 \mathrm{~mm}$ 
respectively under different treatments. This revealed that moisture use during early growth i.e. 0 to $28.12 \%$ growing season is less over mid period i.e. 28.12 to 76.56 per cent growing season of crop and it further decreased during 76.56 to 100.0 percent growing season of gram under all treatment. This variation in moisture use during different period in growing season of crop was mainly due to varied moisture requirement of crop during different crop growth stages and climatological factors.

Total moisture use and moisture use efficiency (MUE) of soybean and chickpea

Considering total productivity and total moisture use of soybean and chickpea, moisture use efficiency was calculated and the data pertaining to moisture use efficiency (MUE kg ha ${ }^{-1} \mathrm{~mm}^{-1}$ ) under different treatment are presented in table 2 .

In soybean maximum moisture use was recorded under $\mathrm{T}_{1}$ (no gypsum) and lowest moisture use was recorded under treatment $\mathrm{T}_{7}$ (5 $\mathrm{t}$ gypsum $\mathrm{ha}^{-1}$ ). Moisture use slightly decreases due to increase in level of gypsum.
Data indicated that there was significant effect of different gypsum treatments on the seed yield of soybean. Treatment $\mathrm{T}_{6}(3 \mathrm{t}$ gypsum $\mathrm{ha}^{-1}$ ) recorded the highest soybean seed yield $\left(19.25 \mathrm{q} \mathrm{ha}^{-1}\right)$ which was at par with treatment $\mathrm{T}_{7}$ (5 $\mathrm{t}$ gypsum ha ${ }^{-1}$ )

Application of $1.5 \mathrm{t}$ gypsum per hectare $\left(\mathrm{T}_{3}\right)$ gave $18.64 \mathrm{q} \mathrm{ha}^{-1}$ seed yield of soybean which was superior over no gypsum $\left(\mathrm{T}_{1}\right)$ and $1.0 \mathrm{t}$ gypsum per hectare $\left(\mathrm{T}_{2}\right)$ and found at par with increasing levels of gypsum. Percent increase in the yield of soybean due to increasing level of gypsum was found in the range of $7.3 \mathrm{t} 19.3$ percent over no gypsum application (Table 3).

Application of gypsum significantly increased the MUE of soybean, maximum MUE $3.10 \mathrm{~kg}$ $\mathrm{ha}^{-1} \mathrm{~mm}^{-1}$ was found under treatment $\mathrm{T}_{6}(3 \mathrm{t}$ gypsum ha ${ }^{-1}$ ) which is significantly superior over treatment $T_{1}$ (no gypsum) and $T_{2}(1 \mathrm{t}$ gypsum $\mathrm{ha}^{-1}$ ) and at par with treatment $\mathrm{T}_{7}, \mathrm{~T}_{5}$, $\mathrm{T}_{4}$ and $\mathrm{T}_{3}$. This indicated that treatment $\mathrm{T}_{3}$ low level of gypsum $\left(1.5 \mathrm{t} \mathrm{ha}^{-1}\right)$ was sufficiently maintaining electrolyte concentration in percolating water which helps in stabilization of soil structure to receive good yield and moisture use efficiency.

Table.1 Location and treatment details

\begin{tabular}{|c|c|c|c|}
\hline 1 & Location & : & Agronomy Farm, College of Agriculture, Nagpur. \\
\hline \multirow[t]{2}{*}{2} & Name of the crop & : & Soybean (JS-335) \\
\hline & (Rabi) & : & Chickpea (JAKI -9218) \\
\hline 3 & Design of experiment & : & Randomized Block Design (RBD) \\
\hline 4 & No. of Treatments & : & 7 \\
\hline 5 & No of Replication & : & 3 \\
\hline 6 & Total no. of plots & : & 21 \\
\hline \multirow[t]{2}{*}{7} & Plot size & : & Gross $6 \times 5.4 \mathrm{~m}$ \\
\hline & & : & Net $4 \times 3.6 \mathrm{~m}$ \\
\hline \multirow[t]{2}{*}{8} & (soybean) & : & $30 \times 5 \mathrm{~cm}^{2}$ \\
\hline & (Chickpea) & : & $30 \times 10 \mathrm{~cm}^{2}$ \\
\hline \multirow[t]{2}{*}{9} & Fertilizer dose & : & 30:75:00 NPK kg ha ${ }^{-1}$ \\
\hline & (Chickpea) & : & 25:50:00 NPK kg ha ${ }^{-1}$ \\
\hline \multirow[t]{2}{*}{10} & (soybean) & : & $80 \mathrm{~kg} \mathrm{ha}^{-1}$ \\
\hline & (Chickpea) & : & $100 \mathrm{~kg} \mathrm{ha}^{-1}$ \\
\hline \multirow[t]{2}{*}{11} & Method of sowing & : & Drilling \\
\hline & (Chickpea) & : & Drilling \\
\hline
\end{tabular}


Table.2(a) Moisture use by soybean during different period of percent growing season of soybean

\begin{tabular}{|c|c|c|c|c|c|c|}
\hline \multirow[t]{2}{*}{ Treatments } & \multicolumn{3}{|c|}{$\begin{array}{c}\text { Moisture use }(\mathrm{mm}) \text { during different period } \\
\text { of } \% \text { growing season }\end{array}$} & \multicolumn{3}{|c|}{$\begin{array}{l}\text { Cumulative Moisture use ( } \mathrm{mm}) \\
\text { at different growing season of } \\
\text { crop. }\end{array}$} \\
\hline & 0-33.3\% & $33.3-67.74$ & $67.74-100.0 \%$ & $33.3 \%$ & $67.74 \%$ & $100.0 \%$ \\
\hline $\mathrm{T}_{1}$ & 242.88 & 192.35 & 256.37 & 242.88 & 435.23 & 691.6 \\
\hline $\mathrm{T}_{2}$ & 226.56 & 224.08 & 197.36 & 226.56 & 450.64 & 648.0 \\
\hline $\mathrm{T}_{3}$ & 215.13 & 210.8 & 200.37 & 215.13 & 425.93 & 626.3 \\
\hline $\mathrm{T}_{4}$ & 208.97 & 211.15 & 221.78 & 208.97 & 420.12 & 641.9 \\
\hline $\mathrm{T}_{5}$ & 222.17 & 208.44 & 197.69 & 222.17 & 430.61 & 628.3 \\
\hline $\mathrm{T}_{6}$ & 214.22 & 209.27 & 196.91 & 214.22 & 423.49 & 620.4 \\
\hline $\mathrm{T}_{7}$ & 214.84 & 211.15 & 187.61 & 214.84 & 425.99 & 613.6 \\
\hline
\end{tabular}

Table.2(b) Moisture use by gram during different percent of growing season of chickpea

\begin{tabular}{|c|l|r|r|r|r|r|}
\hline \multirow{2}{*}{ Treatments } & \multicolumn{3}{|c|}{$\begin{array}{c}\text { Moisture use } \\
\text { period of \%m) during different }\end{array}$} & \multicolumn{3}{c|}{$\begin{array}{c}\text { Cumulative Moisture use (mm) at } \\
\text { different }\end{array}$} \\
\cline { 2 - 7 } & $\mathbf{0 - 2 8 . 1 2 \%} \%$ & $\mathbf{2 8 . 1 2 - 7 6 . 5 6 \%}$ & $\mathbf{7 6 . 5 6 - 1 0 0 \%}$ & $\mathbf{2 8 . 1 2 \%}$ & $\mathbf{6 4 . 8 4 \%}$ & $\mathbf{1 0 0 \%}$ \\
\hline $\mathrm{T}_{1}$ & 51.1 & 94.91 & 30.4 & 51.1 & 110.51 & 176.41 \\
\hline $\mathrm{T}_{2}$ & 63.1 & 135.87 & 25.81 & 63.1 & 143.00 & 224.78 \\
\hline $\mathrm{T}_{3}$ & 51.86 & 105.13 & 25.31 & 51.86 & 125.41 & 182.3 \\
\hline $\mathrm{T}_{4}$ & 57.08 & 121.51 & 16.15 & 57.08 & 154.72 & 194.74 \\
\hline $\mathrm{T}_{5}$ & 61.33 & 117.17 & 19.29 & 61.33 & 150.81 & 197.79 \\
\hline $\mathrm{T}_{6}$ & 65.45 & 113.57 & 20.47 & 65.45 & 151.68 & 199.49 \\
\hline $\mathrm{T}_{7}$ & 55.41 & 100.53 & 13.2 & 55.41 & 134.33 & 169.14 \\
\hline
\end{tabular}

Table.3 Effect of gypsum on seed yield and MUE of soybean and chickpea

\begin{tabular}{|c|c|c|c|c|c|c|}
\hline Treatments & \multicolumn{3}{|c|}{ Soybean } & \multicolumn{3}{c|}{ Chickpea } \\
\cline { 2 - 7 } & $\begin{array}{c}\text { Seed yield } \\
(\mathrm{q} \mathrm{ha}\end{array}$ & $\begin{array}{c}\text { Total } \\
\text { moisture } \\
\text { use }(\mathrm{mm})\end{array}$ & $\begin{array}{c}\text { MUE } \\
\left(\mathrm{kg} \mathrm{ha}^{-1}\right. \\
\left.\mathrm{mm}^{-1}\right)\end{array}$ & $\begin{array}{c}\text { Seed yield } \\
\left(\mathrm{q} \mathrm{ha}^{-1}\right)\end{array}$ & $\begin{array}{c}\text { Total } \\
\text { moisture } \\
\text { use }(\mathrm{mm})\end{array}$ & $\begin{array}{c}\text { MUE } \\
\left(\mathrm{kg} \mathrm{ha}^{-1}\right. \\
\left.\mathrm{mm}^{-1}\right)\end{array}$ \\
\hline $\mathbf{T}_{\mathbf{1}}$ & 15.53 & 691.6 & 2.24 & 9.56 & 176.41 & 5.42 \\
\hline $\mathbf{T}_{\mathbf{2}}$ & 16.75 & 648.0 & 2.58 & 10.69 & 224.78 & 4.75 \\
\hline $\mathbf{T}_{\mathbf{3}}$ & 18.64 & 626.3 & 2.97 & 11.11 & 182.3 & 6.09 \\
\hline $\mathbf{T}_{\mathbf{4}}$ & 18.62 & 641.9 & 2.90 & 11.38 & 194.74 & 5.84 \\
\hline $\mathbf{T}_{\mathbf{5}}$ & 18.73 & 628.3 & 2.98 & 11.71 & 197.79 & 5.92 \\
\hline $\mathbf{T}_{\mathbf{6}}$ & 19.25 & 620.4 & 3.10 & 11.69 & 199.49 & 5.85 \\
\hline $\mathbf{T}_{\mathbf{7}}$ & 18.85 & 613.6 & 3.07 & 12.22 & 169.14 & 7.22 \\
\hline SE $\mathbf{( m )}$ & 0.13 & - & 0.54 & 0.13 & - & 0.07 \\
\hline C.D. at 5\% & 0.41 & - & 1.69 & 0.42 & - & 0.21 \\
\hline
\end{tabular}


The highest moisture use efficiency under treatment $T_{7}$ was might be due to better physical condition, which intern helps in increasing the yield. Similar effect of gypsum was also noted by Sagare et al., (2001), in Vertisols of Purna valley.

In chickpea total moisture use recorded under different treatment varied between 169.14 $\mathrm{mm}$ to $224.78 \mathrm{~mm}$. Maximum moisture use recorded under treatment $\mathrm{T}_{2}(1.0 \mathrm{t}$ gypsum $\mathrm{ha}^{-1}$ ) $224.78 \mathrm{~mm}$ and minimum moisture use recorded under treatment $\mathrm{T}_{7}(5 \mathrm{t}$ gypsum $\left.\mathrm{ha}^{-1}\right)$. However, moisture use slightly decreases with increase levels of gypsum while variation in total moisture use was not much.

Highest seed yield of the chickpea $12.22 \mathrm{q}$ $\mathrm{ha}^{-1}$ recorded under treatment $\mathrm{T}_{7}(5 \mathrm{t}$ gypsum $\mathrm{ha}^{-1}$ ) followed by treatment $\mathrm{T}_{5}$ and minimum seed yield of the chickpea (9.56 q ha ${ }^{-1}$ ) recorded under treatment $\mathrm{T}_{1}$ (no gypsum). Gypsum application at the rate of $1.5 \mathrm{t}$ per hectare $\left(T_{3}\right)$ gave significantly higher yield over no gypsum treatment $\left(\mathrm{T}_{1}\right)$.

The maximum moisture use efficiency in chickpea was registered under treatment $T_{7}$ (7.22 $\mathrm{kg} \mathrm{ha}^{-1} \mathrm{~mm}^{-1}$ ) as against minimum recorded in control $\mathrm{T}_{2}\left(4.75 \mathrm{~kg} \mathrm{ha}^{-1} \mathrm{~mm}^{-1}\right)$. The maximum MUE recorded in $\mathrm{T}_{7}$ mainly due to the maximum yield recorded under same treatment as there was not much variation found in moisture use. The MUE of chickpea recorded under Vertisol varied over 5.50 to $4.61 \mathrm{~kg}^{-1} \mathrm{ha}^{-1} \mathrm{~mm}^{-1}$ as observed by Hajare et al., (1997).

\section{Assessment of moisture availability period (Growing period)}

The data presented in figure 1 indicated that the length of LGP of these soils was 175 days for the year 2009-10. The pattern of rainfall and PET and $1 / 2$ PET indicated humid period of 119 days and moist period of 140 days, which was from June to mid of October. The average soil moisture content across the 15 days interval at $30-60 \mathrm{~cm}$ depth are also presented in figure 2 . The soil moisture content up to $30 \mathrm{~cm}$ did not show much variation among the treatments even though it varied among the month in accordance with the rainfall pattern. Interestingly the soil moisture content at $30-60 \mathrm{~cm}$ depth was considerably higher throughout the year in the Gypsum treated plots with higher in $\mathrm{T}_{7}$.

The higher moisture content in subsoil especially during the dry month would have definitely resulted in higher yield. Here gypsum facilitated downward movement of water. Thus the moisture storage at subsurface layer is improved by gypsum treatment. At the end of October the moisture in subsoil depleted fast and storage of moisture was less in no gypsum soil than the gypsum treated soil. This may be attributed to higher moisture transmission of surface longer due to addition of gypsum.

The LGP based on climatological data could not be appropriate for the planning as the highest depletion of soil moisture in subsoil was observed at the end of October. The further increase of this moisture was attributed to slight irrigation given at 15 October 2009 to chickpea.

In conclusions, application of gypsum does not markedly affect the cumulative moisture use during and at different percent growing season of soybean and chickpea. However MUE of soybean significantly increased with increasing level of gypsum.

Higher MUE was found with $\mathrm{T}_{6}$ (3 $\mathrm{t}$ gypsum $\left.\mathrm{ha}^{-1}\right)$ but $\mathrm{T}_{3}\left(1.5 \mathrm{t}\right.$ gypsum ha $\left.\mathrm{h}^{-1}\right)$ is enough to increase MUE of soybean significantly over no gypsum. Increasing level of gypsum also increase the MUE of chickpea. 


\section{References}

Balpande, S.S., S.B. Deshpande and D.K. Pal, 1996. Factors and processes of soil degradation in Vertisols of the Purna valley, Maharashtra, India. Land degradation and development. 7: 313324.

Balpande, S.S., S.B. Deshpande and D.K. Pal, 1997. Plasmic fabric of Vertisols of Purna valley of India in relation to their cracking. J. Indian Soc. Soil Sci. 45(3): 553-562.

Dhopate, A.M., S.B. Amarshettiwar and R.C. Kalane, 1994. Moisture use by hybrid sorghum PKV. Res. J. 8(1): 65-72.

Emerson, W.W. and Bakker, A.C. 1973. The comparative effect of exchangeable calcium, magnesium and sodium on some physicall properties of red-brown earth sub-soil II the spontaneous dispersion of aggregates in water. Australian J. Soil Reserch II,151-157.

Emerson, W.W.1983. Inter-particle bonding. In:Division of soil, CSIRO, Melbourne, Australia. Soils: an Australian view point. Academic Press London,477-498

Gokhan Ozsoy and Ertugrul Aksoy, 2007. Characterization, classification and agricultural usage of Vertisols developed on neogen aged calcareous marl parent materials. J. Biol. Environ. Sci. 1(1), 5-10.

Kadu, P.R., D.K. Pal and S.B. Deshpande,
1993. Effect of low exchangeable sodium on hydraulic conductivity and drainage in shrink swell soils of Purna valley, Maharashtra, Clay Research. 12: 65-70.

Kadu, P.R., P.H. Vaidya, S.S. Balpande, P.L.A. Satyavathi and D.K. Pal, 2003. Use of hydraulic conductivity to evaluate the suitability of Vertisols for deep rooted crops in semiarid parts of central India. Soil use and Management 19: 208-216.

Kalane, R.L., B.N. Sagare, Y.S. Guhe and R.A. Marathe, 1990. Moisture use pattern and yield of hybrid sorghum under different moisture conservation practices on vertic ustochrepts. Annals of plant physiology 9(1): 1-8.

Michael, A.M. and T.P. Ojha, 2000. Principles of Agriculture Engineering vol. 2 Jain Brothers, Ratanda Road, Jodhpur: 272-283.

Pojasok, T., And B.D. Kay,1990. Effect of root exudates from corn and bromegrass on soil structural stability. Canadian Journal of Soil Science 70: 351-362.

Sagare, B.N., S.S. Retwalkar and V.P. Babhulkar, 2001. Effect of land configuration and gypsum level on dynamics of soil properties and productivity of cotton grown in sodic Vertisols. J. Indian Soc. Soil Sci. 49(2): 377-379.

\section{How to cite this article:}

Kishor R. Shedge, Priyanka N. Hiradeve and Prashant B. Kardile. 2018. Effect of Different Levels of Gypsum on Pattern of Moisture Use and Aggregation in Vertisols under SoybeanChickpea Sequence. Int.J.Curr.Microbiol.App.Sci. 7(12): 1414-1423.

doi: https://doi.org/10.20546/ijcmas.2018.712.169 